\title{
As comunidades negras rurais nas ciências sociais no Brasil: de Nina Rodrigues à era dos programas de pós-graduação em antropologia
}

\section{Carlos Alexandre B. Plínio dos Santos}

\section{(2) OpenEdition \\ Journals}

Edição electrónica

URL: http://journals.openedition.org/aa/1343

DOI: 10.4000/aa.1343

ISSN: 2357-738X

Editora

Programa de Pós-Graduação em Antropologia Social (UnB)

Edição impressa

Data de publição: 1 julho 2015

Paginação: 75-106

ISSN: 0102-4302

Refêrencia eletrónica

Carlos Alexandre B. Plínio dos Santos, «As comunidades negras rurais nas ciências sociais no Brasil: de Nina Rodrigues à era dos programas de pós-graduação em antropologia», Anuário Antropológico [Online], v.40 n. 1 | 2015, posto online no dia 01 junho 2018, consultado o 28 abril 2021. URL: http:// journals.openedition.org/aa/1343 ; DOI: https://doi.org/10.4000/aa.1343

\section{(c)}

Anuário Antropológico is licensed under a Creative Commons Atribuição-Uso Não-Comercial-Proibição de realização de Obras Derivadas 4.0 International. 


\section{As comunidades negras rurais nas ciências sociais no Brasil: de Nina Rodrigues à era dos programas de pós-graduaçáo em antropologia}

Carlos Alexandre B. Plínio dos Santos

$\mathrm{UnB}$

Durante várias décadas, no Brasil, houve uma grande carência de trabalhos científicos sobre o negro brasileiro em contexto rural. O negro em contexto urbano, ao contrário, foi pauta de vários estudos, que privilegiavam discussões sobre seus aspectos físicos e culturais. Com efeito, muitos estudiosos, ao pesquisarem grupos negros, destacaram traços culturais de origem africana, os quais seriam indicativos de uma etnicidade. Esses traços seriam mais nítidos em grupos de negros urbanos, e sua ausência indicaria uma diferenciação apenas no nível do preconceito racial. Como observado por Bandeira (1988:21), pesquisadores como Roger Bastide, Florestan Fernandes e Emília Viotti da Costa, que comungavam com esse ponto de vista, defendiam a tese de que

as condiçóes de vida do negro em situaçáo rural eram culturalmente desagregadoras, posto que dificultavam a persistência de cultos, ritos, tradiçóes e deixavam-lhes poucas ocasiôes e espaços de interação entre si. A vida urbana em relação à vida rural oferecia melhores condições de persistência de traços culturais africanos e, conseqüentemente, de maior potencialidade de formação de uma identidade étnica forjada na resistência cultural.

Tal posicionamento contribuiu para que o foco das pesquisas sociológicas e antropológicas sobre o negro recaísse em contextos urbanos. As comunidades negras rurais, ao serem vistas como "desagregadas culturalmente", foram colocadas à margem das pesquisas acadêmicas do final do século XIX até a segunda metade do século XX.

Neste artigo, pretendo justamente elucidar, por meio de um panorama histórico dos estudos sobre relaçóes raciais nas ciências sociais no Brasil, como se deram as mudanças de foco das pesquisas sociológicas e antropológicas sobre o negro. Nessa direção, discutirei quatro momentos históricos principais (período heroico, de Nina Rodrigues a Édson Carneiro; período carismático, de Donald Pierson a Florestan Fernandes; período burocrático, do Projeto Unesco aos programas de pós-graduação em antropologia - PPGA; e a era do estudo sobre as comunidades negras rurais nos PPGAs), evidenciando o modo como a ênfase quase exclusiva 
nos negros urbanos foi dando espaço, a partir da década de 1960, a uma maior visibilidade dos negros em ambiente rural.

Para além disso, na última parte deste artigo serão listadas dissertações e teses em antropologia cujo foco são as comunidades negras rurais ou o negro em ambiente rural. Trata-se de trabalhos produzidos entre 1960, quando havia apenas um PPGA, e dezembro de 2013, ano em que a Coordenação de Aperfeiçoamento de Pessoal de Nível Superior (Capes) registrou 22 PPGAs em funcionamento no Brasil. ${ }^{1}$ Ante a dificuldade em pesquisar in loco as teses e dissertaçóes nas cidades em que estáo localizados os 22 PPGAs, pesquisa que ultrapassaria os objetivos do presente artigo, explorei o banco de teses e dissertaçóes dos sítios dos PPGAs; das bibliotecas virtuais dessas instituições; do Instituto Brasileiro de Informação em Ciência e Tecnologia (Ibict); e da Capes. Para essa exploração, foram utilizadas as palavras-chaves: campesinato, negro, quilombola, relaçôes raciais, racismo, comunidade negra e escravidão.

\section{Período heroico: de Nina Rodrigues a Édson Carneiro}

A segunda metade do século XIX foi marcada por um contexto intelectual dominado por uma concepção evolucionista do mundo. Segundo essa concepçáo a humanidade era uma só, com uma única origem ou história, e teria se desenvolvido linearmente por estágios. Cada estágio seria caracterizado por um padrão de comportamento, de forma que todas as sociedades que se encontrassem no mesmo estágio de evolução seriam semelhantes entre si, ainda que jamais tivessem tido qualquer tipo de contato umas com as outras.

Nessa época, o universo intelectual era bastante influenciado pelas ciências naturais e, nesse contexto, a biologia e a psicologia fisiológica - matérias cujas fronteiras se confundiam - tiveram papel decisivo no estabelecimento de uma teoria que marcava uma correlação entre cultura e raça, sendo esta última tida como determinante no comportamento humano. Nessas teorias, havia um determinismo hierárquico racial em que negros, índios e mestiços estavam em níveis inferiores aos das pessoas brancas.

Os primeiros estudos sobre o negro no Brasil seguiram essa argumentação. $\mathrm{O}$ pensamento de Raimundo Nina Rodrigues pode ser visto como ilustrativo desse período. Médico por formação e professor da Faculdade de Medicina da Bahia, ele escreveu, entre 1886 e 1906, uma série de artigos sobre medicina, associada muitas vezes à questão racial. Em suas obras, sua preocupação repousava em estabelecer critérios rigorosos de classificação das raças (Corrêa, 2001). Ao utilizar a raça como parâmetro biológico principal da desigualdade, Nina Rodrigues combinou-a com outros indicadores, também biológicos, para responder a questóes sociais. Em 
um de seus mais famosos livros, Os africanos no Brasil, publicado em 1932, após seu falecimento, encontram-se vários artigos escritos num segundo momento de sua produçáo intelectual, quando sua preocupação estava calcada em observaçóes históricas e etnográficas.

Diferentemente de Nina Rodrigues, Francisco Oliveira Vianna contribuiu bastante na propagação dos ideais racistas. Em seu livro Evolução do povo brasileiro (1923), principalmente na segunda parte, "Evolução da raça", fica claro seu apoio ao mito do arianismo. $\mathrm{O}$ autor apregoa diferenças hierárquicas entre brancos, negros e índios, descrevendo esses dois últimos grupos como negativos para a formação da civilização brasileira. Oliveira Vianna defendia que somente com a migração de uma massa ariana pura esse problema poderia ser solucionado, dado que tal massa aumentaria rapidamente o teor ariano no sangue dos brasileiros, o que levaria ao progresso da sociedade brasileira. Em 1932, Oliveira Viana publica o livro Raça e assimilação, porém, ainda preso a ideias raciais de autores do século XIX, continuava a desprezar qualquer argumentação histórica ou etnológica, valorizando abusivamente o biológico (Laraia, 1997).

Na década de 1930, surge no Brasil uma geraçáo de intelectuais preocupados em produzir pesquisas sociais voltadas para a compreensão dos problemas do país, a qual enxergava a mestiçagem como constitutiva da identidade nacional (Schwarcz, 2007). Entre esses intelectuais, destacam-se Sérgio Buarque de Hollanda, que em 1936 publicou Raízes do Brasil, e Caio Prado Jr., autor de Formaçấo econômica do Brasil contemporâneo, de 1942. Porém, foi a partir dos trabalhos de Gilberto Freyre, na década de 1930, que os estudos das relaçóes raciais começaram a sofrer grandes mudanças.

$\mathrm{Na}$ Universidade de Colúmbia, Freyre foi aluno do antropólogo Franz Boas, que o ensinou a diferenciar raça de cultura. Essa diferenciação fica clara em seu livro Casa-grande \& senzala, publicado em 1933. Nesse livro, Freyre fez uma interpretação dos grupos raciais que compóem a sociedade brasileira, desqualificando os argumentos biológicos e introduzindo os estudos culturalistas como modelo de análise. Posteriormente, o autor utilizaria o critério históricocultural, para focar os acontecimentos singulares no tempo e no espaço, a fim de encontrar os traços culturais passíveis de observação sobre as raças.

Tendo como enfoque a miscigenação e o mulato como símbolo da democracia racial, Freyre apontou o contato sexual entre senhores brancos e escravos negros como ponto de partida para a elaboraçáo de seus conceitos a respeito da informalidade e da flexibilidade racial. A miscigenação, para ele, seria uma solução brasileira para os diferentes padróes culturais e teria causado uma democratização social no país. Ele partiu do pressuposto de que a formaçáo brasileira seria 
marcada por "um processo de equilíbrio de antagonismos", que teria resultado num processo de harmonização. Para Laraia (1986), Casa-grande \& senzala

[...] se constitui na verdade no depositário de toda uma ideologia racial, que se expressa através de uma constelação de mitos que tradicionalmente a têm sustentado. $\mathrm{O}$ mito do luso-tropicalismo, que se choca com a realidade da "África portuguesa", o mito do "senhor amável" (cf. Harris, 1964:65-78), uma variante da representação cordial do homem brasileiro; e, finalmente, o mito da democracia racial, desde que para Freyre o preconceito existente decorre da situação de classe e não de raça (Laraia, 1986:163).

Outro estudioso que influenciou os estudos sobre relaçóes raciais no Brasil foi o médico Arthur Ramos. Em 1928, ele foi nomeado legista do Instituto Nina Rodrigues, em Salvador, Bahia. Foi nesse período que nasceu seu interesse sobre a questão do negro no Brasil, pois já era conhecido nacionalmente como discípulo de Afrânio Peixoto e herdeiro intelectual de Nina Rodrigues (Corrêa, 2001). Na década de 1930, Ramos publicou, com a ajuda de Édson Carneiro e a colaboraçáo de Afrânio Peixoto e Maria Amélia Couto Nina Rodrigues (Dona Marica), viúva de Nina Rodrigues, duas obras deste: $O$ animismo fetichista dos negros baianos (1935) e As coletividades anormais (1939).

Havia, segundo Corrêa (2001), sensíveis diferenças teóricas entre Ramos e Nina Rodrigues. As principais seriam: a) a ênfase de Ramos na aculturação e acomodação racial, em contraposição à análise do conflito racial de Nina Rodrigues; b) a análise de Ramos sobre o conceito de "afro-luso-brasileiro", que era mais próxima de Gilberto Freyre do que de Nina Rodrigues; c) a relevância da psicanálise nas obras de Ramos entre 1933 e 1937; e d) o uso do método psicanalítico de Arthur Ramos — depois assumindo o método "culturalista" de Franz Boas, em contraposição ao método histórico-evolutivo de Nina Rodrigues (Barbosa, 2002).

Em 1934, Arthur Ramos publicou uma de suas obras mais importantes, O negro brasileiro: etnografia religiosa e psicanálise. Neste livro, utilizando a psicanálise no estudo da cultura, discutiu a origem étnica dos negros brasileiros e suas manifestaçóes culturais, além de se dedicar ao estudo do sincretismo religioso entre religiôes africanas e religióes "brancas" (catolicismo e espiritismo). Seus estudos tiveram como base empírica os negros da cidade de Salvador. Nessa obra, Ramos trabalhou com o pensamento pré-lógico de Levy-Bruhl, como afirmou Laraia (1986:162): "se Nina Rodrigues errou porque se atrelou ao racismo de Gobineau, Ramos pecou por adotar o etnocentrismo de Levy-Bruhl, expresso em sua teoria sobre o pensamento pré-lógico". 
Posteriormente, em 1937, Ramos lançou o livro As culturas negras no novo mundo, segundo o próprio autor, um ensaio de psicologia social e antropologia cultural. Nessa obra, discutiu com os principais teóricos sobre a temática negra na América - Herskovits, Freyre, Fernando Ortiz, entre outros —, ao examinar os padrôes de culturas que os negros transportaram da África para o Novo Mundo e o destino que tiveram. Para isso, demonstrou, por meio de estudo comparativo, as influências que as culturas negras tiveram no quadro étnico-cultural do Brasil, da região do Caribe e dos Estados Unidos. Em 1943, publicou uma extensa pesquisa bibliográfica sobre as populaçóes de origem africana, entre outros temas, condensada em dois volumes de sua Introdução à antropologia brasileira. Ramos publicou ainda outros livros, todos tendo como temática principal as relaçóes raciais.

Outro pesquisador que recebeu certa influencia dos estudos de Nina Rodrigues foi Manuel Raimundo Querino. Descendente de africanos e autodidata, Manuel Querino trabalhou como assistente de pesquisas de Nina Rodrigues. Foi também recruta na Guerra do Paraguai, pintor, escritor e desenhista - diplomado pelo Liceu de Artes e Ofícios da Bahia. Chegou a ser membro da Câmara Municipal pelo Partido Republicano em Salvador e era abolicionista da Sociedade Libertadora Sete de Setembro, na Bahia (Aguiar, 1955). Antes de Gilberto Freyre, Querino já trabalhava em suas obras a cultura negra pelo aspecto históricocultural, demonstrando as contribuiçóes culturais dessa cultura na sociedade baiana e brasileira. Nesse sentido, diferenciava-se da linha argumentativa de Nina Rodrigues e se aproximava da teoria culturalista de Boas.

Apesar de certas divergências teóricas, Nina Rodrigues influenciou também os estudos de Édson Carneiro, pesquisador negro, filho do escritor Antonio Joaquim Souza Carneiro - estudioso da cultura afro-brasileira que publicou, em 1937, o livro Os mitos africanos no Brasil. Édson Carneiro diplomou-se, em 1936, em ciências jurídicas e sociais pela Faculdade de Direito da Bahia. Com Arthur Ramos, divulgou, nas décadas de 1930 e 1940, o pensamento da "escola Nina Rodrigues" (Corrêa, 2001). Foi um dos fundadores da Sociedade Brasileira de Antropologia e Etnologia em 1941. Movido pela temática cultural negra, Édson Carneiro escreveu diversos livros.

Os estudos sobre o negro, desencadeados por Nina Rodrigues, Afrânio Peixoto e Gilberto Freyre, cada qual com suas especificidades, exerceram influência na formação intelectual de Arthur Ramos e Édson Carneiro. Mariza Corrêa (1998) relata que Freyre afirmava ter aconselhado Ramos a estudar antropologia e largar o psicanalismo e seus "excessos marxistas". Nessa linhagem, estabelecida pela 
conciliação de ideias sobre a questão racial, fica clara a constituição das filiações acadêmicas no campo das ciências sociais (Peirano, 1992).

$\mathrm{Na}$ divisão que faz da história da antropologia, Roberto Cardoso de Oliveira chama esse primeiro período de "heroico". Caracteriza-o como marcado pelo conceito de cultura, pelos aspectos românticos e pela náo institucionalização da disciplina. Para ele, os autores mais fortes desse período foram Curt Nimuendajú, pela temática etnologia indígena, e Gilberto Freyre, pela antropologia da sociedade nacional (Cardoso de Oliveira, 1988).

\section{Período carismático da antropologia: de Donald Pierson a Florestan Fernandes}

$\mathrm{Na}$ década de 1930, teve início a institucionalização das ciências sociais com a criação, em 1933, da Escola Livre de Sociologia e Política de São Paulo (ELSP) e, em 1934, da Faculdade de Filosofia, Ciências e Letras (FFCL) na USP. A primeira tinha como objetivo a formação de funcionários técnicos para as administraçóes do país; já a segunda, a formação de professores secundários (Rubim, 1996). A FFCL, em seus primeiros anos, teve como alunos Egon Schaden, Gioconda Mussolini, Florestan Fernandes, Lucila Hermann, Jurn Philipson, Carlos Drumond e Antonio Candido, entre outros. Alguns desses alunos estudavam simultaneamente nas duas instituiçóes (Pierson \& Cunha, 1947).

Em 1939, com a admissão de Donald Pierson como professor de sociologia e antropologia social da ELSP, desenvolveu-se uma base acadêmica que procurava incentivar a formaçáo de cientistas na área social por meio de pesquisa empírica (Rubim, 1996). Pierson foi o principal representante teórico da Escola de Chicago no Brasil. Formou, entre 1939 e 1949, duas geraçóes de pesquisadores, entre eles Oracy Nogueira e Florestan Fernandes (Mendoza, 2005). Pierson iniciou seus estudos sobre a integração e a mobilidade social dos negros na Bahia em 1935, sob a orientação de Robert Ezra Park. Para Park, o Brasil era um laboratório de relações raciais, por ser um país onde não havia "problema racial". Tal afirmação se baseava em viagens de visitantes americanos ao Brasil, como James Byrce e Theodore Roosevelt (Guimarães, 2004). Ao seguir a tese de Park, Pierson adotou a hipótese de que o preconceito racial seria o principal obstáculo à integração dos negros, em detrimento dos aspectos de aculturação.

Pierson foi responsável pela criação, em 1941, da pós-graduação na ELSP e, em 1942, publicou nos Estados Unidos o livro Negroes in Brazil: a Study of a Race Contact at Bahia, resultado de suas pesquisas na Bahia de 1935 a 1937. Essa obra enfocava as relaçóes raciais entre negros e brancos em Salvador, tida por Pierson como uma cidade medieval. Para o autor, em Salvador não havia grupos raciais ou 
de cor, por isso não existia o racismo. Nesse sentido, a discriminação com base na raça tinha caráter individual e não coletivo. Pierson ressaltava que o problema dos descendentes dos escravos era econômico e educacional, de modo nenhum racial. A Bahia seria então um exemplo da convivência pacífica entre brancos europeus e africanos para o mundo, especialmente para os Estados Unidos (Pierson, 1942). Segundo Laraia (1986:165),

os trabalhos de Freyre e de Pierson caracterizam a primeira das posiçóes acadêmicas sobre o assunto: aquela que atribui às diferenças de classes e das tensôes sociais o problema do negro. A segunda posição seria aquela que, mesmo admitindo a existência do preconceito, alega que o critério de cor é irrelevante para a definição dos diversos grupos sociais.

A Bahia também atraiu a pesquisadora Ruth Landes, que iniciou seus estudos no Brasil como doutoranda em antropologia da Universidade de Colúmbia, em 1938. Em suas pesquisas, Landes apontou singularidades do candomblé da cidade de Salvador, por exemplo, a tendência ao aumento gradual do poder feminino e do número de mães de santo nos candomblés mais tradicionais, e de "homossexuais passivos" nos candomblés de caboclo. Além disso, demonstrou como a noção de "ciência da cultura", trabalhada pelos americanos entre os anos 1930 e 1960, substituía a ideia de raça como paradigma central da disciplina. Publicou, em 1947, os resultados de sua pesquisa no livro The City of Women, editado em português somente em 1967, pela Civilização Brasileira.

No início da década de 1940, iniciaram os trabalhos antropológicos do médico Thales de Azevedo. Nessa época, após contato com Josué de Castro, num curso de extensão sobre alimentação e nutrição na Universidade do Brasil, localizada no Rio de Janeiro, Azevedo começou seus estudos voltados para aspectos sociais da saúde e da medicina que passariam a dominar a sua produção intelectual. Em 1943, assumiu a primeira cadeira de antropologia e etnografia, na recémcriada Faculdade de Filosofia da Universidade da Bahia, dirigindo seu interesse para a antropologia cultural. Posteriormente, foi convidado por Anísio Teixeira para dirigir, com Charles Wagley, da Universidade de Colúmbia, e Luiz Aguiar da Costa Pinto, da Universidade do Brasil, o projeto de Pesquisas Sociais da Universidade de Colúmbia (Maio, 1999).

Azevedo exerceu, por meio de seus escritos, grande influência nos estudos sobre relaçôes raciais no Brasil. Entre suas obras sobre essa temática, destacase Cultura e situação racial no Brasil (1966). Nessa obra, preocupado com os processos culturais e sociais, base dos problemas brasileiros, o autor discute as relaçôes entre mestiçagem, preconceito, estereótipos e status social; a integração 
social; e o sincretismo religioso. Ao analisar a importância da cultura e da situação racial no Brasil, esforça-se em descrever e entender a realidade nacional.

Nesse contexto, há que destacar as influências do antropólogo Melville Jean Herskovits nos estudos sobre as relaçôes raciais no Brasil. ${ }^{2}$ Ex-aluno de Franz Boas, Herskovits, tendo como alicerce suas reflexôes sobre o relativismo cultural, orientou antropólogos como Octávio da Costa Eduardo, René Ribeiro e Ruy Coelho. Costa Eduardo defendeu, em 1948, a tese The Negro in Northern Brazil, a Study in Acculturation, na Universidade de Washington. Nesse trabalho, estudou comparativamente uma comunidade negra rural na cidade de Santo Antônio e outra comunidade negra urbana em São Luís, estado do Maranhão. Seu objetivo foi destacar aspectos da cultura negra africana nessas duas comunidades. A tese de Costa Eduardo foi a primeira a ter como objeto de pesquisa uma comunidade negra rural. René Ribeiro defendeu sua dissertação de mestrado The Afrobrazilian CultGroups of Recife - a Study in Social Adjustment na Universidade Northwestern, em 1949. Em sua tese, trabalhou com grupos negros na cidade de Recife. Já Ruy Coelho realizou seu trabalho de campo em Honduras e defendeu sua tese de doutorado, The Black Carib of Honduras, a Study in Acculturation, na Universidade Northwestern, em 1955.

Em 1943, no período de institucionalização da antropologia, com o apoio de Heloisa Alberto Torres, diretora do Museu Nacional, foi organizado um projeto para promover o primeiro Congresso Brasileiro de Antropologia, em comemoração à reabertura daquele museu no Rio de Janeiro. Porém, somente em 1948, por meio de uma portaria do ministro da Educação e Saúde, foi constituída uma comissão para organizar o congresso. Essa comissão foi composta inicialmente por Álvaro Fróes da Fonseca, Edgar Roquette-Pinto, Arthur Ramos e Heloisa Alberto Torres (Corrêa, 1997). Na data da reunião da comissão, porém, divergências entre Ramos e Torres fizeram com que os dois fossem representados por Castro Faria. Somente cinco anos depois dessa reunião, ou seja, em 1953, foi realizado o Congresso, nas dependências do Museu Nacional, sob a presidência de Herbert Baldus. Nesse evento, nasceram as primeiras ideias para a criação da Associação Brasileira de Antropologia (ABA), em 1955, na Bahia. A ABA foi sucessora da Sociedade Brasileira de Antropologia e Etnologia (SBAE), fundada por Ramos em 1941 (Azeredo, 1986; Corrêa, 1997).

$\mathrm{Na}$ década de 1950 foram criados, no Rio de Janeiro, os primeiros cursos na área de etnologia indígena. Em 1955, o primeiro foi o Curso de Aperfeiçoamento em Antropologia Cultural, no Museu do Índio, órgão do então Serviço de Proteção aos Índios. O curso foi desenhado por Darcy Ribeiro e teve a colaboração docente, entre outros, de Roberto Cardoso de Oliveira. O segundo curso ocorreu em 1957, 
também por iniciativa de Darcy Ribeiro: Curso de Formação de Pesquisadores Sociais, promovido no Centro Brasileiro de Pesquisas Educacionais (Melatti, 1983).

Nessa década, Ramos, Freyre e Herskovits, por meio da imagem que sustentaram internacionalmente de que o Brasil era um grande "laboratório das relaçóes raciais", contribuíram, com o sociólogo Franklin Frazier, para o desenvolvimento do projeto da Organização das Naçóes Unidas para a Educação, a Ciência e a Cultura (Unesco) no Brasil. Segundo esses intelectuais, o Brasil poderia ser a vitrine para outros povos aprenderem sobre a convivência pacífica entre negros e brancos. Observa-se que o objetivo do projeto não era entender como funcionavam as relaçóes culturais entre negros e brancos no Brasil, e sim como as ideologias que estavam nessas relaçóes poderiam servir de instrumento na transformação consciente de outras sociedades, principalmente a europeia, em direção a uma ordem justa (Maio, 1999).

Inspirada por essa imagem, a Unesco patrocinou, de 1951 a 1952, várias pesquisas sobre as relaçóes raciais no Brasil. As primeiras investigaçóes foram desenvolvidas em Salvador — posteriormente, foram abrangidas as cidades de São Paulo e Rio de Janeiro, com o objetivo de demonstrar os detalhes de uma experiência no campo das interaçóes raciais no Brasil. Participaram dessas pesquisas Ruy Coelho, Alfred Métraux, Thales de Azevedo, Charles Wagley, Roger Bastide, Luiz de Aguiar Costa Pinto, Paulo Esteváo de Berredo Carneiro e Gilberto Freyre, entre outros (Maio, 1999). Conforme Thales de Azevedo (1996:16), esses estudos apontaram que atuava no Brasil "um preconceito étnico cautelosamente disfarçado pela ideologia da não-discriminação".

Como parte desses estudos da Unesco, foi publicado apenas em francês, em 1952, o livro Race et classes dans le Brésil rural, com os seguintes ensaios: "Les relations raciales dans une communauté rurale Du Recôncavo (État de Bahia)", de Harry William Hutchinson; "Les relations raciales à Minas Velhas, communauté rurale de la région montagneuse du Brésil central”, de Marvin Harris; "Les relations raciales dans la région aride du sertão", de Ben Zimmerman; e por último "Les relations raciales dans une communauté rurale de l'Amazonie", de Charles Wagley. Trata-se de uma coletânea, organizada por Charles Wagley, de ensaios sobre estudos de relaçóes raciais em áreas rurais.

Apesar da primazia desse trabalho no que se refere às relaçóes raciais em zonas rurais, Wagley estava preocupado em observar a existência ou não do preconceito de raça. Ao final das pesquisas, concluiu que os estudos confirmavam as teorias de Pierson (1942) de que, no Brasil, quer na zona rural, quer na urbana, não existia preconceito de raça e sim de classes sociais. Essa assertiva estava próxima da 
interpretação de Freyre (1994) sobre a convivência relativamente harmônica entre grupos raciais no Brasil. Como observaram Bastide e Fernandes, na obra Brancos e negros em São Paulo (1959), o problema de Wagley e Pierson foi generalizar uma conjuntura racial peculiar da Bahia para o restante do Brasil.

Foi a partir dos anos 1950, com as pesquisas de Fernandes, que ocorreu no Brasil uma mudança na abordagem dos estudos sobre a questão racial. Crítico do mito da "democracia racial", um postulado de Freyre, Fernandes demonstrava a temática racial por meio do ângulo da desigualdade. Sua trajetória acadêmica teve início em 1944, quando concluiu, com poucas condiçóes financeiras, o curso de bacharelado e licenciatura em ciências sociais na FFCL/USP. Nessa época, foram seus professores Roger Bastide, Emílio Willems, Alfred Radcliffe-Brown e Donald Pierson, entre outros (Ianni, 2004b). Posteriormente, entre 1946 e 1947, cursou pós-graduação em sociologia e antropologia na ELSP. Em 1947, defendeu sua dissertação de mestrado $A$ organização social dos Tupinambá e, em 1951, doutorou-se com a tese $A$ funçâo social da guerra na sociedade Tupinambá. Nesses dois trabalhos acadêmicos, Fernandes utilizou-se do método funcionalista (Melatti, 1983). Em 1953, fez a livre-docência com o trabalho Ensaio sobre o método de interpretação funcionalista na sociologia, e em 1964 tornou-se catedrático com a obra $A$ integração do negro na sociedade de classes (Ianni, 2004b). ${ }^{3}$

Nessa obra, Fernandes introduziu novos parâmetros, novas vertentes sociológicas e o materialismo histórico para a reflexão teórica da interpretação da realidade social brasileira. $\mathrm{O}$ autor examinou a situação do negro na cidade de São Paulo a partir da abolição da escravatura, tendo como referência a sociedade de classes. Questionou a ideia de "democracia racial" ao atribuir a desigualdade racial a duas heranças do regime escravocrata que impediram os negros de competir com os imigrantes: o racismo e a incapacidade de integração à ordem social competitiva (Rios \& Mattos, 2005). Segundo as pesquisadoras Rios e Mattos,

para Fernandes, a herança deformadora da escravidáo seria apenas um dos fatores a explicar a desorganização social que ele percebia como característica da população negra. Essa desorganização se traduziria na ausência de ligaçôes familiares sólidas, de iniciativa e disciplina de trabalho, de solidariedade de raça ou de classe, levando a um tipo de comportamento por vezes patológico. Para a explicação dessa situação de patologia social, teriam contribuído elementos conjunturais e psicológicos, e não apenas a herança. Assim, as expectativas frustradas dos libertos com a liberdade, o rápido desenvolvimento da cidade em moldes capitalistas e competitivos e a introdução dos imigrantes europeus em larga escala teriam contribuído também para a desorganização social do negro. [...] Fernandes sugere que a ordem racial herdada da escravidão foi um 
dado estrutural que persistiu, sobrevivendo ao pós-abolição (Rios \& Mattos, 2005:20-21).

Há que ressaltar que tanto Fernandes como Freyre, dois marcantes pensadores sobre as relações raciais no Brasil, abordam a estrutura social, que é feita de tensóes e movimentos; porém, o primeiro a retrata pelo viés da harmonia social (miscigenação racial), e o segundo, pelo conflito social (classes sociais). Freyre e Fernandes diferem profundamente em suas avaliaçóes do modo pelo qual a escravidão determinou a atual configuração das relaçōes raciais no Brasil. No entanto, apresentam dois pontos em comum: consideravam a escravidão o fator determinante da situação racial do Brasil, e seus estudos focalizavam a construção do Estado-nação.

Para Cardoso de Oliveira, o período entre o final dos anos 1940 e o princípio da década de 1950 foi o "período carismático da antropologia”, caracterizado pela introdução do conceito de estrutura. Florestan Fernandes - no campo da antropologia da sociedade nacional — e Eduardo Galvão — no campo da etnologia de vertente culturalista — foram figuras centrais desse período. Eles conseguiram reunir em torno de si e de seus projetos científicos e acadêmicos inúmeros estudantes de antropologia (Cardoso de Oliveira, 1988), entre os quais o próprio Cardoso de Oliveira.

\section{Período burocrático: do Projeto Unesco aos PPGAs}

$\mathrm{Na}$ metade da década de 1950, como desdobramento do Projeto Unesco, iniciou-se a pesquisa de Fernandes sobre as relaçóes raciais na região meridional do Brasil (Paraná, Santa Catarina e Rio Grande do Sul). A pesquisa contou com a participação do pedagogo Anísio Teixeira, do antropólogo Charles Wagley e dos sociólogos Fernando Henrique Cardoso e Octávio Ianni. Cardoso e Ianni iniciaram suas carreiras acadêmicas sob a orientação de Fernandes, cujas pesquisas sobre a condição social dos negros descendentes de escravos foram fruto do convite insistente de Bastide e do financiamento da Unesco (Garcia Jr., 2004).

O Projeto Unesco influenciou direta ou indiretamente a realização de várias pesquisas que resultaram em publicaçóes sobre a questão racial brasileira. Entre as publicaçóes, destacam-se: $O$ negro no Rio de Janeiro: relaçóes de raças numa sociedade em mudança (1954), de Costa Pinto; As elites de cor numa cidade brasileira: um estudo de ascensão social (1955), de Azevedo; Relaçôes raciais no município de Itapetininga (1955), de Nogueira; Brancos e negros em São Paulo: ensaio sociológico sobre aspectos da formação, manifestaçóes atuais e efeitos do preconceito de cor na 
sociedade paulistana (1959), de Bastide e Fernandes; e A integração do negro na sociedade de classes (1965), de Fernandes.

Ocorreram também influências desse projeto nos trabalhos de Ianni e Cardoso. Em Ianni, em sua dissertação de mestrado, Raça e mobilidade social em Florianópolis, defendida em 1956, e em sua tese de doutorado, Negros na sociedade de castas, defendida em 1961. Com relação a Cardoso, em sua tese de doutorado, Capitalismo e escravidão no Brasil meridional, defendida em 1962. Essas duas teses, orientadas por Fernandes, trouxeram a problemática da integração dos negros à sociedade de classes formada no período pós-abolição. A primeira retratou as relaçóes raciais em Santa Catarina, e a segunda, no Rio Grande do Sul.

Posteriormente, Cardoso e Ianni publicaram o livro Cor e mobilidade social em Florianópolis: aspectos das relaçóes entre negros e brancos numa comunidade do Brasil meridional (1960). Segundo os autores, o Brasil estaria se transformando em uma sociedade de classes, e a estratificação por raça seria uma herança do passado colonial que, embora persistisse, seria aos poucos substituída por discriminaçóes de classe. As desvantagens raciais existiam como um legado do passado de escravidão. Apesar da grande influência teórica de Fernandes nessa obra, Cardoso e Ianni conseguiram desvendar o preconceito racial e tudo que o envolve como crença ou conduta. Ou seja, para os autores, a atitude preconceituosa para com o negro é apenas a parte mais evidente de uma verdadeira ideologia legitimadora do controle exercido por uma etnia sobre a outra (Brandão, 1977).

Em 1954, Nogueira marcou sua entrada na discussão sobre as relaçóes raciais ao apresentar seu texto "Preconceito racial de marca e preconceito racial de origem sugestão de um quadro de referência para a interpretação do material sobre relaçóes raciais no Brasil" no XXXI Congresso Internacional de Americanistas. Segundo Guimarães (1999:169), esse artigo

[...] serviu também de síntese erudita da dicotomia entre o Brasil e os Estados Unidos, em termos das relações entre brancos e negros. Era o ingrato destino de uma reflexão, que fora apropriada por uma política identitária nacionalista que buscava, a todo custo, firmar o caráter "democrático" e "brando" das relaçôes raciais no Brasil, em contraste com o resto do mundo, notadamente os Estados Unidos.

No Brasil, os estudos sobre as relaçóes raciais foram explorados, sobretudo, por sociólogos. Entre os poucos antropólogos que se dedicaram a elas, destaca-se João Baptista Borges Pereira (Melatti, 1983), que, inspirado ainda pelas pesquisas da Unesco, defendeu sua dissertação de mestrado em antropologia, Cor, profissáo e mobilidade: o negro e o rádio de Sáo Paulo, em 1964, na USP, sob a orientação 
de Egon Schaden. O autor realizou extensa pesquisa de campo entre 1959 e 1964 e, ao utilizar o rádio como objeto de análise, investigou dois processos: "a integração do homem de cor à faixa de convivência sócio-profissional"; e "a participaçáo na sociedade e cultura amplas desse contingente humano que ganhou novas qualificaçôes sociais, através de sua integração à estrutura das empresas radiofônicas" (Borges Pereira, 1967:20).

Esse período também foi marcado pela mudança geográfica das pesquisas sobre relaçôes raciais no Brasil. Num primeiro momento, essas pesquisas estavam concentradas na Bahia e em Pernambuco; posteriormente, passaram a ter como referência São Paulo, estendendo-se, em seguida, para Paraná, Santa Catarina e Rio Grande do Sul. Foram os estudos do Projeto Unesco, com novas perspectivas teóricas, que motivaram a mudança geográfica das pesquisas sobre relações raciais no Brasil. Segundo Ianni (2004b), essa mudança ocorreu em virtude de São Paulo, na época, já ser uma sociedade de classes e mais urbanizada. A sociedade de classes estava em franco desenvolvimento, havendo, portanto, uma sociabilidade diferente daquela existente no Nordeste, a qual estaria próxima a uma sociedade de castas.

[...] Acredito que isso levou Caio Prado, Florestan Fernandes, Roger Bastide e Oracy Nogueira a perceberem que esse cenário era um laboratório excepcional para a análise de problemas sociais. Aqui [Sáo Paulo] a questão racial aparecia de uma maneira mais explícita. [...] Enfatizo esse argumento de que no patamar em que eles estavam - a sociedade do Centro-Sul - havia uma urbanização intensa e recente, classes sociais evidentemente em formação e a industrialização, onde foi possível descortinar que o preconceito racial não se reduzia ao preconceito de classe (Ianni, 2004b:12).

$\mathrm{Na}$ década de 1960, ganharam força os "estudos de comunidade", "fundamentados na observação direta de pequenas cidades ou vilas com as técnicas desenvolvidas pela Etnologia no estudo das sociedades tribais" (Melatti, 1983:17). ${ }^{4}$ Para Melatti (1983:18),

[...] com os estudos de comunidade pretendia-se chegar a uma visão geral da sociedade brasileira, através da soma de muitos exemplos distribuídos pelas diversas regióes do Brasil. Além desse objetivo geral, tais estudos estavam quase sempre voltados para objetivos específicos, como mudança cultural, persistência da vida tradicional, problemas de imigrantes, educação e vários outros.

Até 1960, segundo Melatti (1983), a antropologia brasileira caracterizouse pela justaposição das influências europeia e norte-americana, as quais foram 
responsáveis pela união um tanto híbrida, respectivamente, de funcionalismo com aculturação.

Foi principalmente a partir da década de 1970, impulsionada pela formação dos programas de pós-graduação em antropologia, que houve a terceira grande mudança no campo dos estudos de relaçóes raciais, pois as comunidades negras rurais, ou o negro em ambiente rural, começaram a ser alvo de pesquisas antropológicas. Essa perspectiva teve início nas fundamentações teóricas de Roberto Cardoso de Oliveira sobre identidade e etnia, bem como nas pesquisas de Otávio Velho, Klaas Woortmann e João Baptista Borges Pereira, sobre campesinato e comunidades negras rurais.

\section{O estudo sobre as comunidades negras rurais na era dos PPGAs}

Como já assinalado, os estudos sobre as relações raciais passaram por várias interpretaçôes, ganhando fôlego com a institucionalização das ciências sociais, em 1933, mais especificamente com a criação da ELSP, e, em 1934, com a formação da FFCL/USP. Posteriormente, na década de 1960, com os primeiros PPGAS do Museu Nacional/UFRJ (1968), da Unicamp (1971) e da UnB (1972) —, essa institucionalização entrou numa fase de consolidação.

Desde o início dos PPGAs no Brasil - mestrado e doutorado - até dezembro de 2013, foram produzidas 2.512 dissertaçóes de mestrado e 938 teses de doutorado. Desses trabalhos, 77 tiveram como foco, direto ou indireto, as comunidades negras rurais e/ou o negro em ambiente rural (Anexo 1). ${ }^{5}$

\begin{tabular}{|c|c|c|c|c|c|}
\hline $\begin{array}{c}\text { Instituição e ano } \\
\text { de criação do } \\
\text { PPGA }\end{array}$ & $\begin{array}{c}\text { Dissertações } \\
\text { produzidas }\end{array}$ & $\begin{array}{c}\text { Teses } \\
\text { produzidas }\end{array}$ & $\begin{array}{c}\text { Dissertações } \\
\text { sobre } \\
\text { comunidades } \\
\text { negras rurais }\end{array}$ & $\begin{array}{c}\text { Teses sobre } \\
\text { comunidades } \\
\text { negras rurais }\end{array}$ & $\begin{array}{c}\text { Total sobre } \\
\text { comunidades } \\
\text { negras rurais }\end{array}$ \\
\hline UnB (1972) & 307 & 121 & 16 & 5 & 21 \\
\hline UFRGS (1979) & 255 & 88 & 8 & 4 & 12 \\
\hline $\begin{array}{c}\text { Museu Nacional/ } \\
\text { UFRJ (1968) }\end{array}$ & 550 & 366 & 4 & 3 & 7 \\
\hline USP (1972) & 206 & 193 & 3 & 3 & 6 \\
\hline UFSC (1985) & 238 & 64 & 3 & 2 & 5 \\
\hline UFPE (1977) & 106 & 52 & 5 & - & 5 \\
\hline Unicamp (1971) & 280 & 7 & 3 & - & 3 \\
\hline UFF (1994) & 161 & 28 & 1 & 3 & 4 \\
\hline UFMG (2005) & 51 & - & 4 & - & 4 \\
\hline UFPR (1991) & 165 & 14 & - & - & - \\
\hline UFRN (2005) & 41 & - & 8 & - & 8 \\
\hline UFBA (2006) & 7 & 1 & - & - & - \\
\hline
\end{tabular}




\begin{tabular}{|c|c|c|c|c|c|}
\hline UFPA (2010) & 8 & - & 1 & - & 1 \\
\hline UFPI (2008) & 15 & - & - & - & - \\
\hline UFSE (2009) & 31 & - & - & - & - \\
\hline Ufam (2008) & 20 & - & - & - & - \\
\hline UFG (2009) & 23 & - & 1 & - & 1 \\
\hline UFSCar (2007) & 48 & 4 & - & - & - \\
\hline $\begin{array}{c}\text { UFPEL, UFGD e } \\
\text { UFPB, UFMT }\end{array}$ & - & - & - & - & - \\
\hline Total & $\mathbf{2 . 5 1 2}$ & $\mathbf{9 3 8}$ & $\mathbf{5 7}$ & $\mathbf{2 0}$ & $\mathbf{7 7}$ \\
\hline
\end{tabular}

Tabela 1 - Dissertaçóes e teses por PPGA sobre comunidades negras rurais (1968 - 2013)

De acordo com esses dados, podemos depreender que os PPGAs que mais pesquisaram as comunidades negras rurais no mestrado foram os da UnB (16 dissertaçóes), da UFRGS (8 dissertaçóes) e da UFRN (8 dissertaçóes). No doutorado, o PPGA da UnB continua em primeiro, com 5 teses, seguido do programa da UFRGS, com 4 teses. Ao realizar este levantamento, percebi que o volume de trabalhos acadêmicos inseridos nessa temática vem crescendo lentamente. Para uma melhor análise dessa produção, dividi a "era da pósgraduação em antropologia” em três períodos.

\begin{tabular}{|c|c|c|c|}
\hline Períodos & Dissertações & Teses & Total do período \\
\hline Início dos PPGAs a 1988 & 6 & 2 & 8 \\
\hline 1989 a 2003 & 14 & 3 & 17 \\
\hline 2004 a 2013 & 37 & 15 & 52 \\
\hline Total dos períodos & $\mathbf{5 7}$ & $\mathbf{2 0}$ & $\mathbf{7 7}$ \\
\hline
\end{tabular}

Tabela 2 - Os três períodos da era dos PPGAs

O primeiro período inicia-se com a criação dos PPGAs e vai até 1988 - ano em que foi promulgada a Constituição Federal brasileira, na qual foi inserido, no Ato das Disposiçóes Constitucionais Transitórias, o artigo 68, que estabeleceu direitos territoriais para os remanescentes das comunidades dos quilombos. $\mathrm{O}$ segundo período vai de 1989 a 2003 — ocasião em que foi criado o Decreto no 4.887, que regulamentou o procedimento de regularização fundiária das terras ocupadas por remanescentes das comunidades dos quilombos. $\mathrm{O}$ terceiro começa em 2004 e finaliza em 2013, data final desta pesquisa.

Para uma análise das teses e dissertações dos PPGAs, temos que nos remeter à conjuntura em que foram produzidas, pois as temáticas escolhidas pelos pesquisadores estão relacionadas com seus contextos temporais. No primeiro período, destaco os seguintes temas: identidade; relaçóes interétnicas (negro e branco); bairro rural (forte influência dos "estudos de comunidade"); trabalho 
(produção e economia); parentesco; religiosidade (aqui estão inseridas as festas aos santos); e frentes de expansão e conflito de terra.

No segundo período, os temas giraram em torno de etnicidade; movimento negro; territorialidade; religiosidade; conflito de terra; legislação (principalmente o artigo 68 do Ato das Disposiçóes Constitucionais Transitórias); e identidade e parentesco. Nesse período, várias comunidades negras rurais começaram a ser analisadas como remanescentes de quilombos. Iniciava também nesse momento o processo de ruptura da antropologia com a historiografia sobre a conceituação do termo "quilombo".

No terceiro período, as temáticas estavam assim focadas: legislação/direitos (principalmente o Decreto 4.887/03); territorialidade; parentesco; papel do antropólogo; identidade; quilombo rural e/ou urbano; religiosidade; conflito de terra; movimento quilombola e relações interétnicas (negros, índios e brancos). Nessa fase, boa parte das teses e dissertaçôes foi realizada tendo como fio condutor a territorialidade agregada à identidade quilombola e o referencial teórico centrado na categoria grupo étnico.

Vários trabalhos desse terceiro período também enfatizam a recriação de elementos da memória, servindo os laços das comunidades negras atuais com grupos do passado para materializar e construir o presente etnográfico. Isso levou essas comunidades a estabelecerem uma nova relaçáo com o passado, reconstruindo-o. Hobsbawm e Ranger (2008) chamaram esse fato de "invenção de tradição", isto é, uma reapropriação de velhos modelos ou antigos elementos de cultura e de memória para novos fins, em que o passado serve como conjunto de conhecimentos simbólicos. Como afirmou Klaas Woortmann (1990:17), “a tradição, então, não é o passado que sobrevive no presente, mas o passado que, no presente, constrói as possibilidades do futuro".

Apesar de as teses e dissertaçóes abordarem diversas temáticas em diferentes décadas, aplico, como forma de análise, o "princípio dialógico", que "consiste em manter a dualidade no seio da unidade" (Morin, 1990:107). Nesse sentido, observo que, nos três períodos da era dos PPGAs, as "comunidades negras rurais" foram pesquisadas seguindo uma única estrutura baseada nas categorias culturais nucleantes, centrais para o campesinato: terra, família e trabalho. Segundo Woortmann (1990:23), essas categorias "são nucleantes e, sobretudo, relacionadas, isto é, uma não existe sem a outra”. Woortmann (1990:23) considera

[...] a cultura como o universo de representaçóes de um grupo, categoria ou sociedade. [...] Percebo a cultura ainda como um sistema onde diferentes núcleos de representações estão em comunicação uns com os outros, como que formando uma rede de significados. Essas categorias nucleantes agregam 
conjuntos de significaçóes, os quais, em sua comunicação dentro do universo de representaçôes, se articulam e compóem uma totalidade. [...] Assim, naturalmente, cada cultura terá categorias nucleantes específicas, mas, ao que parece, existem certas categorias comuns às sociedades camponesas em geral, como terra, família e trabalho.

As temáticas abordadas pelas teses e dissertaçóes analisadas estão articuladas por essas categorias culturais nucleantes, as quais se ligam diretamente à reproduçáo social do campesinato. Como detectou Durham (1973), em seus estudos sobre migraçáo rural, ocorre uma uniformidade e permanência de elementos tradicionais na sociedade rural brasileira.

[...] Essa uniformidade se deve, sobretudo à semelhança fundamental na constituição da unidade produtiva, que é a família conjugal, no modo de organização dessa unidade em grupos de vizinhança, nos padróes e técnicas de trabalho e na possibilidade de acesso ao meio de produção essencial, a terra (Durham, 1973:46, grifos meus).

Nesse sentido, independentemente dos contextos sociopolíticos e das temporalidades, na sombra de todas as pesquisas está a reprodução social das comunidades negras rurais, as quais possuem como princípios organizatórios as categorias culturais nucleantes terra, família e trabalho.

Ainda na esfera acadêmica, foram criados vários grupos de pesquisas que investigam, direta ou indiretamente, as comunidades negras rurais/quilombolas. Esse fato também tem ajudado a aumentar o número de pesquisadores que estudam essas comunidades. De acordo com o Diretório dos Grupos de Pesquisa no Brasil, do CNPq, até 2010, eram 14 grupos cadastrados na área predominante ciências humanas/antropologia (Anexo 2)..$^{7}$ Esses 14 grupos de pesquisa congregam 163 pesquisadores e 131 estudantes envolvidos na produção científica de elementos que estão relacionados com as comunidades negras rurais quilombolas.

\section{Consideraçóes finais}

Atualmente, ao discorrermos sobre as histórias das comunidades negras rurais, trabalhamos com processos sociais dinâmicos que revelam novas facetas da época pós-abolição. A memória coletiva dessas comunidades demonstra as especificidades dos grupos de camponeses negros, seus caminhos de constituição e sua luta em ocupar e garantir a terra. Gusmão (1992:117) faz a seguinte observação sobre esses grupos de camponeses negros:

[...] as especificidades de que são portadores os tornam parte do universo camponês brasileiro e, ao mesmo tempo, os diferenciam a partir da condição 
étnica, da história particular que lhes deu origem. Muitas vezes, vivendo em terras devolutas ou públicas, constituem-se como posseiros; por vezes pequenos proprietários, constroem coletivamente a vida sob uma base geográfica, física e social, formadora de uma territorialidade negra. Dentro dela elaboram-se formas específicas de ser e existir enquanto camponês e negro.

São esses camponeses negros que ficaram à margem, durante décadas, do foco das ciências sociais. Como demonstrado, do período que se iniciou com Nina Rodrigues, passando por Freyre e Fernandes até chegar ao Projeto Unesco, ocorreu uma carência de estudos acadêmicos sobre o negro no contexto rural brasileiro. A partir da década de 1960, com a formação dos primeiros PPGAs, as comunidades negras rurais começaram a ser alvo de estudos acadêmicos. Porém, até os anos 1980, ainda eram poucas as obras científicas sobre essa temática, tendo Borges Pereira (1983:12) observado uma "comprovada falta de trabalhos científicos sobre o negro brasileiro em ambiente rural".

Nas décadas de 1990 e 2000, alguns fatores contribuíram para que houvesse um aumento no número de trabalhos acadêmicos sobre as comunidades negras rurais: a ampliação dos PPGAs; a criação de normas constitucionais e outros dispositivos legais; a atuação política de vários antropólogos; e a atuação do Movimento Negro e do Movimento Quilombola. Outro ponto que merece destaque foi a ressemantização do termo "quilombo" na década de 1990.

Os estudos sobre as comunidades negras rurais, se juntarmos a produção acadêmica de dissertaçóes e teses, os laudos e os relatórios antropológicos e os grupos de pesquisa, vêm passando nos últimos anos por um significativo processo de visibilização tanto no meio acadêmico como fora dele. Nesse sentido, o "fazer antropológico", dentro e fora da academia, tornou-se imprescindível na elaboraçáo de políticas públicas voltadas a essas comunidades. 
Anexo 1 - Teses e dissertaçóes sobre comunidades negras rurais

\begin{tabular}{|c|c|c|c|c|}
\hline № & Título & Ano & Autor & Instituição \\
\hline 1 & $\begin{array}{c}\text { Peões, pretos e congos: relações de } \\
\text { trabalho e identidade étnica }\end{array}$ & 1974 & Carlos R. Brandão & UnB (Mestrado) \\
\hline 2 & $\begin{array}{c}\text { Produção camponesa em Lagoa da } \\
\text { Pedra: etnia e patronagem }\end{array}$ & 1977 & Maria O. da C. Telles & UnB (Mestrado) \\
\hline 3 & $\begin{array}{c}\text { Aqui nós somos pretos: estudo de } \\
\text { etnografias sobre negros rurais no } \\
\text { Brasil }\end{array}$ & 1996 & $\begin{array}{l}\text { Aniceto Catanhede } \\
\text { Filho }\end{array}$ & UnB (Mestrado) \\
\hline 4 & $\begin{array}{c}\text { Isso tudo os velhos sabiam: } \\
\text { representações da velhice na } \\
\text { comunidade rural negra de Rio das } \\
\text { Rãs }\end{array}$ & 1996 & Juliana Sellani & UnB (Mestrado) \\
\hline 5 & $\begin{array}{c}\text { reapropriação da tradição a partir } \\
\text { do presente: um estudo sobre a } \\
\text { Festa de Nossa Senhora do Rosário } \\
\text { de Chapada do Norte/MG }\end{array}$ & 1997 & Liliana de M. Porto & UnB (Mestrado) \\
\hline 6 & \begin{tabular}{|c|} 
Do tempo da fartura dos crioulos \\
ao tempo de penúria dos morenos: \\
a identidade através de um rito em \\
Brejo dos Crioulos
\end{tabular} & 1999 & João B. de A. Costa & UnB (Mestrado) \\
\hline 7 & $\begin{array}{l}\text { Espinho: desconstrução da } \\
\text { racialização negra e escravidão }\end{array}$ & 2000 & Miriam V. R. Rosa & UnB (Mestrado) \\
\hline 8 & $\begin{array}{c}\text { Confrontos discursivos sobre } \\
\text { território no Brasil: o caso das } \\
\text { terras dos remanescentes de } \\
\text { quilombos }\end{array}$ & 2001 & Siglia Z. Doria & UnB (Doutorado) \\
\hline 9 & $\begin{array}{l}\text { A Comunidade Kalunga e a } \\
\text { interpelação do Estado: da } \\
\text { invisibilidade à identidade política }\end{array}$ & 2003 & Danielli J. França & UnB (Mestrado) \\
\hline 10 & $\begin{array}{c}\text { Do tempo da sussa ao tempo do } \\
\text { forró: música, festa e memória } \\
\text { entre os Kalunga de Teresina de } \\
\text { Goiás }\end{array}$ & 2006 & Thaís T. de Siqueira & UnB (Mestrado) \\
\hline 11 & $\begin{array}{l}\text { Quilombo Tapuio (PI): terra de } \\
\text { memória e identidade }\end{array}$ & 2006 & $\begin{array}{c}\text { Carlos Alexandre B. } \\
\text { Plínio dos Santos }\end{array}$ & UnB (Mestrado) \\
\hline 12 & $\begin{array}{l}\text { Aprendendo a ser negro: } \\
\text { reinterpretações acerca da } \\
\text { identidade étnica em São } \\
\text { Cristóvão/MA } \\
\end{array}$ & 2007 & Lea R. Sales & UnB (Mestrado) \\
\hline 13 & $\begin{array}{c}\text { Senhores e possuidores livres } \\
\text { e desembargados: a liberdade } \\
\text { antecipada e o uso solidário da } \\
\text { Terra em Espinho }\end{array}$ & 2007 & Miriam V. R. Rosa & UnB (Doutorado) \\
\hline
\end{tabular}




\begin{tabular}{|c|c|c|c|c|}
\hline 14 & $\begin{array}{c}\text { Conflitos e identidades do passado } \\
\text { e do presente: política e tradição } \\
\text { em um quilombo na Amazônia }\end{array}$ & 2008 & Carmela M. Z. Pereira & UnB (Mestrado) \\
\hline 15 & $\begin{array}{l}\text { Aquilombar-se: um panorama } \\
\text { histórico, identitário e político do } \\
\text { Movimento Quilombola Brasileiro }\end{array}$ & 2008 & Bárbara O. Souza & UnB (Mestrado) \\
\hline 16 & $\begin{array}{c}\text { Os Gurutubanos: territorialização, } \\
\text { produção e sociabilidade de um } \\
\text { quilombo norte-mineiro }\end{array}$ & 2008 & Aderval Costa Filho & UnB (Doutorado) \\
\hline 17 & $\begin{array}{l}\text { Práticas produtivas e políticas } \\
\text { públicas: uma experiência } \\
\text { quilombola no Vale do Ribeira/SP }\end{array}$ & 2010 & Paula B. de Melo & UnB (Mestrado) \\
\hline 18 & $\begin{array}{c}\text { Fiéis descendentes: redes- } \\
\text { irmandades na pós-abolição entre } \\
\text { as comunidades negras rurais } \\
\text { sul-mato-grossenses }\end{array}$ & 2010 & $\begin{array}{l}\text { Carlos Alexandre B. } \\
\text { Plínio dos Santos }\end{array}$ & UnB (Doutorado) \\
\hline 19 & $\begin{array}{c}\text { "Não vê que neste mundo não } \\
\text { tem cabaça". Espacialidades e } \\
\text { identidades em Barra de Aroeira } \\
\text { - TO }\end{array}$ & 2011 & Luciene de O. Dias & UnB (Doutorado) \\
\hline 20 & $\begin{array}{l}\text { Eu moro no prata, no ouro } \\
\text { e no bronze: processos de } \\
\text { territorialidade e etnicidade no } \\
\text { Quilombo Povoado do Prata - TO }\end{array}$ & 2013 & Raoni da Rosa & UnB (Mestrado) \\
\hline 21 & \begin{tabular}{|c|} 
Pro povo é festa, pra gente é \\
outra coisa: cultura popular, raça e \\
políticas públicas na Comunidade \\
Negra dos Arturos
\end{tabular} & 2013 & Caio Csermak & UnB (Mestrado) \\
\hline 22 & $\begin{array}{l}\text { Talhado: um estudo de organização } \\
\text { social e política }\end{array}$ & 1975 & Josefa S. B. Cavalcanti & $\begin{array}{c}\text { Museu Nacional/ } \\
\text { UFRJ } \\
\text { (Mestrado) }\end{array}$ \\
\hline 23 & Campesinato: ideologia e política & 1981 & Luiz E. Soares & $\begin{array}{c}\text { Museu Nacional/ } \\
\text { UFRJ } \\
\text { (Mestrado) }\end{array}$ \\
\hline 24 & $\begin{array}{l}\text { Os Arturos: casa, descendência } \\
\text { e identidade social de uma } \\
\text { comunidade negra de Contagem, } \\
\text { Minas Gerais }\end{array}$ & 1999 & Érika M. B. de Assis & $\begin{array}{c}\text { Museu Nacional/ } \\
\text { UFRJ } \\
\text { (Mestrado) }\end{array}$ \\
\hline 25 & $\begin{array}{c}\text { A Comunidade do Sutil: história e } \\
\text { etnografia de um grupo negro na } \\
\text { área rural do Paraná }\end{array}$ & 2000 & Miriam F. Hartung & $\begin{array}{c}\text { Museu Nacional/ } \\
\text { UFRJ } \\
\text { (Mestrado) }\end{array}$ \\
\hline 26 & $\begin{array}{l}\text { "Etnias federais": o processo de } \\
\text { identificação de "remanescentes" } \\
\text { indígenas e quilombolas no Baixo } \\
\text { São Francisco }\end{array}$ & 2002 & José M. de P. A. Arruti & $\begin{array}{c}\text { Museu Nacional/ } \\
\text { UFRJ } \\
\text { (Doutorado) }\end{array}$ \\
\hline
\end{tabular}




\begin{tabular}{|c|c|c|c|c|}
\hline 27 & $\begin{array}{c}\text { Fazendo a unidade uma perspectiva } \\
\text { comparativa na construção } \\
\text { de Itamoari e de Jamary como } \\
\text { quilombos }\end{array}$ & 2004 & Sara A. Arroyo & $\begin{array}{c}\text { Museu Nacional/ } \\
\text { UFRJ } \\
\text { (Doutorado) }\end{array}$ \\
\hline 28 & $\begin{array}{l}\text { Família, escravidão, luta: histórias } \\
\text { contadas de uma antiga fazenda }\end{array}$ & 2011 & Monica F. Figurelli & $\begin{array}{c}\text { Museu Nacional/ } \\
\text { UFRJ } \\
\text { (Doutorado) }\end{array}$ \\
\hline 29 & $\begin{array}{c}\text { Os caipiras negros do Vale do } \\
\text { Ribeira: um estudo de antropologia } \\
\text { econômica }\end{array}$ & 1980 & Renato da S. Queiroz & $\begin{array}{c}\text { USP } \\
\text { (Mestrado) }\end{array}$ \\
\hline 30 & $\begin{array}{l}\text { Castainho: etnografia de um bairro } \\
\text { rural de negros }\end{array}$ & 1980 & $\begin{array}{l}\text { Anita M. de Q. } \\
\text { Monteiro }\end{array}$ & $\begin{array}{c}\text { USP } \\
\text { (Mestrado) }\end{array}$ \\
\hline 31 & \begin{tabular}{|c|} 
Negros de cedro: estudo \\
antropológico de um bairro rural de \\
negros em Goiás
\end{tabular} & 1981 & Mari de N. Baiocchi & $\begin{array}{c}\text { USP } \\
\text { (Doutorado) }\end{array}$ \\
\hline 32 & $\begin{array}{c}\text { Vila Bela: território branco, espaço } \\
\text { negro; um estudo de identidade } \\
\text { étnica }\end{array}$ & 1986 & Maria de L. Bandeira & $\begin{array}{c}\text { USP } \\
\text { (Doutorado) }\end{array}$ \\
\hline 33 & $\begin{array}{l}\text { Quilombos e políticas de } \\
\text { reconhecimento: o caso do } \\
\text { Campinho da Independência }\end{array}$ & 2009 & Lívia R. Lima & $\begin{array}{c}\text { USP } \\
\text { (Mestrado) }\end{array}$ \\
\hline 34 & $\begin{array}{l}\text { Entre quilombos e palenques: } \\
\text { um estudo antropológico } \\
\text { sobre políticas públicas de } \\
\text { reconhecimento no Brasil e na } \\
\text { Colômbia }\end{array}$ & 2012 & Vera R. R. da Silva & $\begin{array}{c}\text { USP } \\
\text { (Doutorado) }\end{array}$ \\
\hline 35 & $\begin{array}{l}\text { Desdobramentos culturais em } \\
\text { identidades cruzadas: negros } \\
\text { quilombolas e índios Atikum no } \\
\text { sertão de Pernambuco }\end{array}$ & 2000 & $\begin{array}{l}\text { Morgana G. C. de } \\
\text { Oliveira }\end{array}$ & UFPE (Mestrado) \\
\hline 36 & $\begin{array}{c}\text { O quilombo 'Negros de Gilu' } \\
\text { em Itacuruba: emergência } \\
\text { etnoquilombola e territorialidade }\end{array}$ & 2007 & $\begin{array}{l}\text { Tercina M. L. B. } \\
\text { Bezerra }\end{array}$ & $\begin{array}{c}\text { UFPE } \\
\text { (Mestrado) }\end{array}$ \\
\hline 37 & $\begin{array}{c}\text { Serrote do gado brabo: identidade, } \\
\text { territorialidade e migrações em } \\
\text { uma comunidade remanescente de } \\
\text { quilombo }\end{array}$ & 2008 & $\begin{array}{c}\text { Francisco M. G. } \\
\text { Ferreira }\end{array}$ & $\begin{array}{c}\text { UFPE } \\
\text { (Mestrado) }\end{array}$ \\
\hline 38 & $\begin{array}{l}\text { Reconhecimento étnico e políticas } \\
\text { públicas de desenvolvimento } \\
\text { agrário: o caso dos agricultores } \\
\text { quilombolas da comunidade do } \\
\text { Timbó em Pernambuco }\end{array}$ & 2009 & José A. da Silva Júnior & $\begin{array}{c}\text { UFPE } \\
\text { (Mestrado) }\end{array}$ \\
\hline 39 & $\begin{array}{c}\text { Estrela: uma comunidade } \\
\text { quilombola em Pernambuco }\end{array}$ & 2012 & Alice F. do N. Maciel & $\begin{array}{c}\text { UFPE } \\
\text { (Mestrado) }\end{array}$ \\
\hline
\end{tabular}




\begin{tabular}{|c|c|c|c|c|}
\hline 40 & $\begin{array}{c}\text { Festa de Nossa Senhora Imaculada } \\
\text { da Conceição: articulação, } \\
\text { sociabilidade e etnicidade dos } \\
\text { negros do Rincão dos Pretos do } \\
\text { município de Rio Pardo/RS } \\
\end{array}$ & 2001 & Rui L. da S. Santos & $\begin{array}{c}\text { UFRGS } \\
\text { (Mestrado) }\end{array}$ \\
\hline 41 & $\begin{array}{l}\text { O planeta dos negros no mundo } \\
\text { dos brancos: estudo sobre } \\
\text { a manutenção e atualização } \\
\text { das fronteiras étnicas de uma } \\
\text { comunidade negra na cidade de } \\
\text { Canoas/RS }\end{array}$ & 2004 & Ana P. C. de Carvalho & $\begin{array}{c}\text { UFRGS } \\
\text { (Mestrado) }\end{array}$ \\
\hline 42 & $\begin{array}{l}\text { Ritual do maçambique: } \\
\text { religiosidade e atualização da } \\
\text { identidade étnica na comunidade } \\
\text { negra do Morro Alto/RS }\end{array}$ & 2005 & Mariana B. Fernandes & $\begin{array}{c}\text { UFRGS } \\
\text { (Mestrado) }\end{array}$ \\
\hline 43 & $\begin{array}{l}\text { Reconhecimento de direitos face } \\
\text { aos (des)dobramentos da história: } \\
\text { um estudo antropológico sobre } \\
\text { territórios de quilombos }\end{array}$ & 2005 & Miriam de F. Chagas & $\begin{array}{c}\text { UFRGS } \\
\text { (Doutorado) }\end{array}$ \\
\hline 44 & $\begin{array}{c}\text { Comunidade remanescente de } \\
\text { quilombos do Morro Alto: uma } \\
\text { análise etnográfica dos campos de } \\
\text { disputa em torno da construção do } \\
\text { significado da identidade jurídico- } \\
\text { política de remanescentes de } \\
\text { quilombos }\end{array}$ & 2006 & Cíntia B. Müller & $\begin{array}{c}\text { UFRGS } \\
\text { (Doutorado) }\end{array}$ \\
\hline 45 & \begin{tabular}{|} 
'De gente da Barragem’ a \\
'Quilombo da Anastácia': um estudo \\
antropológico sobre o processo de \\
etnogênese em uma comunidade \\
quilombola no município de \\
Viamão/RS
\end{tabular} & 2006 & Vera R. R. da Silva & $\begin{array}{c}\text { UFRGS } \\
\text { (Mestrado) }\end{array}$ \\
\hline 46 & $\begin{array}{c}\text { Entre a Avenida Luís Guaranha } \\
\text { e o Quilombo do Areal: estudo } \\
\text { etnográfico sobre memória, } \\
\text { sociabilidade e territorialidade } \\
\text { negra em Porto Alegre }\end{array}$ & 2006 & Olavo R. Marques & $\begin{array}{c}\text { UFRGS } \\
\text { (Mestrado) }\end{array}$ \\
\hline 47 & \begin{tabular}{|c|} 
Anastácia, Manuel Barbosa e \\
Ferreira Fialho, famílias e territórios \\
negros: tradição e dinâmica \\
territorial em Gravataí e Viamão/RS
\end{tabular} & 2007 & Luciano S. Costa & $\begin{array}{c}\text { UFRGS } \\
\text { (Mestrado) }\end{array}$ \\
\hline 48 & $\begin{array}{l}\text { O espaço da diferença no Brasil: } \\
\text { etnografia de políticas públicas } \\
\text { de reconhecimento territorial e } \\
\text { cultural negro no sul do país }\end{array}$ & 2008 & Ana P. C. de Carvalho & $\begin{array}{c}\text { UFRGS } \\
\text { (Doutorado) }\end{array}$ \\
\hline
\end{tabular}




\begin{tabular}{|c|c|c|c|c|}
\hline 49 & $\begin{array}{c}\text { Entre gingas e cantigas: etnografia } \\
\text { da performance entre os morenos } \\
\text { de Tavares, RS }\end{array}$ & 2010 & Janaina C. Lobo & $\begin{array}{l}\text { UFRGS } \\
\text { (Mestrado) }\end{array}$ \\
\hline 50 & $\begin{array}{c}\text { "O mundo é composto": } \\
\text { territorialidade e cosmologia na } \\
\text { comunidade quilombola Angelim I, } \\
\text { Conceição da Barra - Espírito Santo }\end{array}$ & 2011 & Bethânia D. Zanatta & $\begin{array}{l}\text { UFRGS } \\
\text { (Mestrado) }\end{array}$ \\
\hline 51 & $\begin{array}{c}\text { Sobre raízes e redes: } \\
\text { territorialidades, memórias e } \\
\text { identidades entre populações } \\
\text { negras em cidades contemporâneas } \\
\text { no sul do Brasil }\end{array}$ & 2013 & Olavo R. Marques & $\begin{array}{c}\text { UFRGS } \\
\text { (Doutorado) }\end{array}$ \\
\hline 52 & \begin{tabular}{|} 
O trabalho da memória: um \\
estudo antropológico de ocupação \\
camponesa no sertão do Piauí
\end{tabular} & 1993 & Emilia P. de Godoi & $\begin{array}{l}\text { Unicamp } \\
\text { (Mestrado) }\end{array}$ \\
\hline 53 & $\begin{array}{c}\text { Arte e festa no quilombo: processo } \\
\text { de construção turística de um } \\
\text { bairro rural da Mantiqueira }\end{array}$ & 2004 & Maria E. P. Fortes & $\begin{array}{l}\text { Unicamp } \\
\text { (Mestrado) }\end{array}$ \\
\hline 54 & $\begin{array}{l}\text { Caminhos criativos da história: } \\
\text { territórios da memória em uma } \\
\text { comunidade negra rural }\end{array}$ & 2008 & Marcelo M. Mello & $\begin{array}{l}\text { Unicamp } \\
\text { (Mestrado) }\end{array}$ \\
\hline 55 & $\begin{array}{c}\text { De negros a adventistas, em busca } \\
\text { da salvação. Estudo de um grupo } \\
\text { rural de Santa Catarina }\end{array}$ & 1990 & Vera I. Teixeira & $\begin{array}{c}\text { UFSC } \\
\text { (Mestrado) }\end{array}$ \\
\hline 56 & $\begin{array}{l}\text { No tempo das águas cheias: } \\
\text { memória e história dos negros do } \\
\text { Curiaú - AP }\end{array}$ & 1999 & Joseline S. B. Trindade & $\begin{array}{c}\text { UFSC } \\
\text { (Mestrado) }\end{array}$ \\
\hline 57 & $\begin{array}{c}\text { Projeto político do território negro } \\
\text { de Retiro e as lutas pela titulação } \\
\text { das terras }\end{array}$ & 2005 & Osvaldo M. de Oliveira & $\begin{array}{c}\text { UFSC } \\
\text { (Doutorado) }\end{array}$ \\
\hline 58 & $\begin{array}{l}\text { A constituição local: direito e } \\
\text { território quilombola em Bairro } \\
\text { Alto, Ilha do Marajó, Pará }\end{array}$ & 2008 & Luis F. C. e Cardoso & $\begin{array}{c}\text { UFSC } \\
\text { (Doutorado) }\end{array}$ \\
\hline 59 & $\begin{array}{l}\text { Visagens e profecias: ecos da } \\
\text { territorialidade quilombola }\end{array}$ & 2013 & Raquel Mombelli & $\begin{array}{c}\text { UFSC } \\
\text { (Mestrado) }\end{array}$ \\
\hline 60 & $\begin{array}{l}\text { Negros, parentes e herdeiros - } \\
\text { um estudo da reelaboração da } \\
\text { identidade étnica na Comunidade } \\
\text { de Retiro, Santa Leopoldina - ES }\end{array}$ & 1999 & Osvaldo M. de Oliveira & $\begin{array}{c}\text { UFF } \\
\text { (Doutorado) }\end{array}$ \\
\hline
\end{tabular}




\begin{tabular}{|c|c|c|c|c|}
\hline 61 & $\begin{array}{l}\text { Nem muito mar, nem muita } \\
\text { terra. Nem tanto negro, nem } \\
\text { tanto branco: uma discussão } \\
\text { sobre o processo de construção } \\
\text { da identidade da comunidade } \\
\text { remanescente de quilombos na } \\
\text { Ilhas de Marambaia/RJ }\end{array}$ & 2003 & Fábio Reis Mota & $\begin{array}{c}\text { UFF } \\
\text { (Mestrado) }\end{array}$ \\
\hline 62 & $\begin{array}{c}\text { Canelatiua, terra dos pobres, terra } \\
\text { da pobreza: uma territorialidade } \\
\text { ameaçada, entre a recusa de virar } \\
\text { terra da base e a titulação como } \\
\text { terra de quilombo }\end{array}$ & 2011 & Patrícia P. Nunes & $\begin{array}{c}\text { UFF } \\
\text { (Doutorado) }\end{array}$ \\
\hline 63 & $\begin{array}{c}\text { "Tambor dos pretos": processos } \\
\text { sociais e diferenciação étnica no rio } \\
\text { Jaú, Amazonas }\end{array}$ & 2012 & João Siqueira & $\begin{array}{c}\text { UFF } \\
\text { (Doutorado) }\end{array}$ \\
\hline 64 & $\begin{array}{c}\text { Remanescentes das comunidades } \\
\text { de quilombo: da re-significação ao } \\
\text { imperativo legal }\end{array}$ & 2008 & Carlos E. Marques & $\begin{array}{c}\text { UFMG } \\
\text { (Mestrado) }\end{array}$ \\
\hline 65 & $\begin{array}{l}\text { Herdeiros de Chico Rei: mito } \\
\text { de origem e etnogênese da } \\
\text { comunidade quilombola de } \\
\text { Pontinha }\end{array}$ & 2008 & Ricardo A. da Silva & $\begin{array}{c}\text { UFMG } \\
\text { (Mestrado) }\end{array}$ \\
\hline 66 & $\begin{array}{c}\text { A "textura da vida diária": } \\
\text { materialidade e paisagem no } \\
\text { cotidiano do Quilombo Marques } \\
\text { (Vale do Mucuri/MG) }\end{array}$ & 2011 & $\begin{array}{l}\text { Evelin L. M. } \\
\text { Nascimento }\end{array}$ & $\begin{array}{c}\text { UFMG } \\
\text { (Mestrado) }\end{array}$ \\
\hline 67 & $\begin{array}{c}\text { Organização social e regimes de } \\
\text { propriedades numa comunidade } \\
\text { quilombola paraense }\end{array}$ & 2013 & José C. L. Ferreira & $\begin{array}{c}\text { UFMG } \\
\text { (Mestrado) }\end{array}$ \\
\hline 68 & $\begin{array}{l}\text { Entre parentes: cotidiano, } \\
\text { religiosidade e identidade na serra } \\
\text { de Portalegre - RN }\end{array}$ & 2005 & Glória C. de O. Morais & $\begin{array}{c}\text { UFRN } \\
\text { (Mestrado) }\end{array}$ \\
\hline 69 & $\begin{array}{c}\text { Identidade, memória e narrativas } \\
\text { na dança de São Gonçalo do } \\
\text { povoado Mussuca/SE }\end{array}$ & 2007 & $\begin{array}{l}\text { Wellington de J. } \\
\text { Bonfim }\end{array}$ & $\begin{array}{c}\text { UFRN } \\
\text { (Mestrado) }\end{array}$ \\
\hline 70 & $\begin{array}{c}\text { Os forrós da Serra da Gameleira } \\
\text { (São Tomé/RN): etnicidade, festa e } \\
\text { sociabilidade }\end{array}$ & 2009 & Flávio R. F. Ferreira & $\begin{array}{c}\text { UFRN } \\
\text { (Mestrado) }\end{array}$ \\
\hline 71 & $\begin{array}{c}\text { O zambê é nossa cultura. O coco de } \\
\text { zambê e a emergência étnica em } \\
\text { Simbaúma, Tibau do Sul }\end{array}$ & 2009 & Cyro H. Almeida & $\begin{array}{c}\text { UFRN } \\
\text { (Mestrado) }\end{array}$ \\
\hline 72 & $\begin{array}{c}\text { Antropologia das mediações: } \\
\text { dos "pretos de coqueiros" à } \\
\text { comunidade quilombola do vale do } \\
\text { Ceará Mirim }\end{array}$ & 2010 & Stephanie C. P. Moreira & $\begin{array}{c}\text { UFRN } \\
\text { (Mestrado) }\end{array}$ \\
\hline
\end{tabular}




\begin{tabular}{|c|c|c|c|c|}
\hline 73 & $\begin{array}{c}\text { Natureza de mulher, nome de mãe, } \\
\text { marca de negra: identidades em } \\
\text { trânsito e políticas do corpo na } \\
\text { comunidade quilombola de Boa } \\
\text { Vista dos Negros }\end{array}$ & 2010 & Ana G. E. Boschemeier & $\begin{array}{r}\text { UFRN } \\
\text { (Mestrado) }\end{array}$ \\
\hline 74 & $\begin{array}{c}\text { Nego veio é um sofrer: uma } \\
\text { etnografia da subalternidade e do } \\
\text { subalterno numa irmandade do } \\
\text { Rosário }\end{array}$ & 2012 & Bruno G. M. Silva & $\begin{array}{c}\text { UFRN } \\
\text { (Mestrado) }\end{array}$ \\
\hline 76 & $\begin{array}{c}\text { "É a luta da gente!": juventude } \\
\text { e etnicidade na Comunidade } \\
\text { Quilombola de Capoeiras (RN) } \\
\text { povos do Aproaga: patrimônio } \\
\text { arqueológico e territorialidade } \\
\text { quilombola no Vale do Rio Capim } \\
\text { (PA) }\end{array}$ & 2012 & Maira S. de L. Freire & $\begin{array}{c}\text { UFRN } \\
\text { (Mestrado) }\end{array}$ \\
\hline 77 & $\begin{array}{c}\text { Do tempo dos pretos d'antes aos } \\
\text { Sebastião: aspectos simbólicos } \\
\text { de um ritual na comunidade } \\
\text { quilombola Magalhães - GO }\end{array}$ & 2013 & Reigler S. Pedroza & $\begin{array}{c}\text { UFPA } \\
\text { (Mestrado) }\end{array}$ \\
(Mestrado) \\
\hline
\end{tabular}

\section{Anexo 2-Grupos de pesquisa/CNPq}

\begin{tabular}{|c|c|c|}
\hline № & Nome do grupo & Instituição \\
\hline 1 & $\begin{array}{l}\text { Antropologia do Desenvolvimento e Meio Ambiente } \\
\text { no Piauí }\end{array}$ & UFPI \\
\hline 2 & NUPE - Núcleo Negro para Pesquisa e Extensão & $\begin{array}{l}\text { Universidade Estadual } \\
\text { Paulista }\end{array}$ \\
\hline 3 & $\begin{array}{c}\text { Educação e Relações Étnicas: Saberes e Práticas } \\
\text { Educativas do Legado Africano e Indígenas }\end{array}$ & $\begin{array}{l}\text { Universidade Estadual do } \\
\text { Sudoeste da Bahia }\end{array}$ \\
\hline 4 & $\begin{array}{c}\text { Paiol - Grupo de Pesquisa sobre Cultura e Políticas } \\
\text { Culturais no Meio Rural }\end{array}$ & $\begin{array}{l}\text { Universidade Federal de } \\
\text { Viçosa }\end{array}$ \\
\hline 5 & $\begin{array}{c}\text { NUQ - Núcleo de Estudos de Populações Quilombolas } \\
\text { e Tradicionais }\end{array}$ & UFMG \\
\hline 6 & $\begin{array}{l}\text { O Negro e suas Participações Societárias: na } \\
\text { Educação, na Cultura, na Política, na Economia, na } \\
\text { Religião, na História, na Identidade, na Saúde, na } \\
\text { Mídia e na Seguridade Alimentar }\end{array}$ & $\begin{array}{l}\text { Universidade Federal do } \\
\text { Tocantins }\end{array}$ \\
\hline 7 & $\begin{array}{c}\text { LACED - Laboratório de Pesquisas em Etnicidade, } \\
\text { Cultura e Desenvolvimento }\end{array}$ & UFRJ \\
\hline 8 & $\begin{array}{l}\text { Laboratório de Antropologia dos Processos de } \\
\text { Formação }\end{array}$ & $\begin{array}{l}\text { Pontifícia Universidade } \\
\text { Católica/RJ }\end{array}$ \\
\hline
\end{tabular}




\begin{tabular}{|c|c|c|}
\hline 9 & Grupo de Estudos Rurais e Urbanos & $\begin{array}{c}\text { Universidade Federal do } \\
\text { Maranhão }\end{array}$ \\
\hline 10 & Saberes e Ideologias Tradicionais & UnB \\
\hline 11 & $\begin{array}{c}\text { Núcleo de Pesquisas em Territorialização, Identidade e } \\
\text { Movimentos Sociais }\end{array}$ & UFAM \\
\hline 12 & LAE - Laboratório de Arqueologia e Etnologia & UFRGS \\
\hline 13 & Grupo de Estudo da Cultura Afro-Brasileira & $\begin{array}{c}\text { Universidade Federal Rural } \\
\text { de Pernambuco }\end{array}$ \\
\hline 14 & NEPE - Núcleo de Estudos e Pesquisas sobre \\
Etnicidade & UFPE \\
\hline
\end{tabular}

Recebido em 13/03/2014

Aprovado em 20/05/2014

Carlos Alexandre Barboza Plínio dos Santos é mestre e doutor em antropologia pela Universidade de Brasília/UnB. Realizou Pós-Doutorado no Instituto de Estudos Comparados em Administração Institucional de Conflitos/ InEAC da UFF (bolsa CNPq). Atualmente, é Pesquisador Colaborador Pleno do PPGAS/DAN/UnB, onde realiza estágio pós-doutoral (bolsa Capes). Tem desenvolvido sua investigaçáo na área de antropologia do campesinato e comunidades negras quilombolas. Além de artigos publicados em livros e periódicos científicos, é autor dos livros Negros do Tapuio: memórias de quilombolas do sertâo pianiense (Editora Appris, Curitiba, 2012) e Fiéis descendentes: redesirmandades na pós-abolição entre as comunidades negras rurais sul-mato-grossenses (Editora Universidade de Brasília, Brasília, 2014). Contato: carlosalexandrebps@ gmail.com 


\section{Notas}

1. Os programas de pós-graduação em antropologia são os da: Universidade Federal da Bahia (UFBA); Universidade de Brasília (UnB); Universidade Federal de Minas Gerais (UFMG); Universidade Federal de Pernambuco (UFPE); Universidade Federal Fluminense (UFF); Universidade Federal de Sergipe (UFSE); Universidade Federal do Piauí (UFPI), que possui pós-graduação em antropologia e arqueologia; Universidade Federal do Amazonas (Ufam); Universidade Federal de Goiás (UFG); Universidade Federal do Paraná (UFPR); Universidade Federal do Rio de Janeiro (UFRJ) - Museu Nacional; Universidade Federal do Rio Grande do Norte (UFRN); Universidade Federal do Rio Grande do Sul (UFRGS); Universidade Federal de Santa Catarina (UFSC); Universidade Federal de São Carlos (UFSCar); Universidade Federal do Pará (UFPA); Universidade Estadual de Campinas (Unicamp); Universidade Federal da Grande Dourados (UFGD); Universidade Federal da Paraíba (UFPB); Universidade Federal de Pelotas (UFPEL); Universidade Federal de Mato Grosso (UFMT); e Universidade de São Paulo (USP), que possui pós-graduação em ciências sociais (antropologia e sociologia).

2. Herskovits também exerceu grande influência nas antropologias mexicana e colombiana. No México, seu principal discípulo foi Gonzalo Aguirre Beltrán, que estudou o processo de aculturaçấo nas trocas socioculturais entre negros, índios e brancos e analisou a integração do negro na sociedade de classes daquele país (Aguirre Beltrán, 1967). Na Colômbia, seu discípulo foi José Rafael Arboleda, o primeiro a estudar antropologicamente os grupos negros colombianos (Friedemann, 1984).

3. Fernandes publicou vários livros sobre relaçôes raciais durante sua carreira. Sobre sua obra, ver Florestan Fernandes: sociologia crítica e militante, organizada por Octavio Ianni (2004a).

4. Uma lista desses trabalhos pode ser consultada em Melatti (1983).

5. Ressalto que esse montante pode ser maior. Dados os limites impostos pela não disponibilidade em acessar a íntegra de todos os trabalhos produzidos, algumas teses e dissertaçóes podem não ter sido consideradas.

6. Os PPGAs dessas instituiçôes foram criados a partir de 2011 e não possuíam dissertações e teses defendidas no período da pesquisa.

7. O Diretório dos Grupos de Pesquisa é um projeto desenvolvido no CNPq desde 1992 que se constitui em bases de dados sobre os grupos de pesquisa em atividade no país (Fonte: http://dgp.cnpq.br/buscaoperacional/). 


\section{Referências bibliográficas}

AGUIAR, Pinto de. 1955. "Manuel Querino e sua obra". In: Manuel Querino. A raça africana e seus costumes. Salvador: Progresso.

AGUIRRE BELTRÁN, Gonzalo. 1967. Regiones de refugio: el desarrollo de la comunidad en Mestizo-América. México: Instituto Indigenista Interamericano.

AZEREDO, Paulo R. 1986. Antropólogos e pioneiros: a história da Sociedade Brasileira de Antropologia e Etnologia. São Paulo: FFLCH/USP.

AZEVEDO, Thales de. 1966. Cultura e situação racial no Brasil. Rio de Janeiro: Civilização Brasileira.

1996. As elites de cor numa cidade brasileira: um estudo de ascensão social \& classes sociais e grupos de prestígio. 2. ed. Salvador: EDUFBA/EGBA.

BANDEIRA, Maria de Lourdes. 1988. Território negro em espaço branco: estudos antropológicos de Vila Bela. São Paulo: Brasiliense; CNPq.

BARBOSA, Muryatan S. 2002. A escola Nina Rodrigues na antropologia brasileira. São Paulo: Editora da USP.

BASTIDE, Roger \& FERNANDES, Florestan. 1959. Brancos e negros em São Paulo: ensaio sociológico sobre aspectos da formação, manifestaçôes atuais e efeitos do preconceito de cor na sociedade paulistana. 2. ed. São Paulo: Nacional.

BORGES PEREIRA, João B. 1967. Cor, profissão e mobilidade: o negro e o rádio de São Paulo. São Paulo: Pioneira.

1983. Prefacio. In: Renato da Silva Queiroz. Os caipiras negros no Vale do Ribeira: um estudo de antropologia econômica. São Paulo: FFCH/USP, pp. 9-13.

BRANDÃO, Carlos R. 1977. Peóes, pretos e congos: trabalho e identidade étnica em Goiás. Goiânia: Editora da Universidade de Brasília.

CARDOSO, Fernando H. \& IANNI, Octávio. 1960. Cor e mobilidade social em Florianópolis: aspectos das relaçôes entre negros e brancos numa comunidade do Brasil meridional. São Paulo: Nacional.

CARDOSO DE OLIVEIRA, Roberto. 1988. Sobre o pensamento antropológico. Rio de Janeiro: Tempo Brasileiro; Brasília: CNPq.

CARNEIRO, Antônio J. S. 1937. Os mitos africanos no Brasil. São Paulo: Nacional. (Biblioteca Pedagógica Brasileira, série 5. Brasiliana, v. 103). 
COELHO, Ruy. 1955. The Black Carib of Honduras, a Study in Acculturation. Ph. D. thesis, Northwestern University.

CORRÊA, Mariza. 1998. As ilusóes da liberdade: a escola de Nina Rodrigues e a antropologia no Brasil. 2. ed. Bragança Paulista: Editora da Universidade São Francisco. (Coleção Estudos CDAPH. Série Memória).

. 1997. "Dona Heloisa e a pesquisa de campo". Revista de Antropologia, 40(1): pp. 11-54.

COSTA EDUARDO, Octavio da. 1948. The Negro in Northern Brazil, a Study in Acculturation. New York: J. J. Augustin. (Monographs of the American Ethnological Society, 15).

COSTA PINTO, Luiz de A. 1953. O negro no Rio de Janeiro: relaçóes de raças numa sociedade em mudança. São Paulo: Nacional.

DURHAM, Eunice R. 1973. A caminho da cidade: a vida rural e a migração para São Paulo. São Paulo: Perspectiva. FERNANDES, Florestan. 1965. A integração do negro na sociedade de classes. São Paulo: Dominus; USP. 2 v.

FREYRE, Gilberto. 1994. Casa-grande \& senzala. 29. ed. Rio de Janeiro: Record. Publicado originalmente em 1933.

FRIEDEMANN, Nina S. de. 1984. "Estudios de negros en la antropologia colombiana". In: Jaime Arocha et al. Un siglo de investigación social: antropología en Colombia. Bogotá: ETNO.

GARCIA JR., Afrânio. 2004. "A dependência da política: Fernando Henrique Cardoso e a sociologia no Brasil”. Tempo Social, 16(1): pp. 285-300.

GUIMARÁES, Antonio S. A. 2004. O Projeto Unesco na Bahia. Comunicação ao Colóquio Internacional "O projeto Unesco no Brasil: uma volta crítica ao campo 50 anos depois". Centro de Estudos Afro-Orientais da Universidade Federal da Bahia, Salvador, Bahia, 12-14 jul. 2004.

. 1999. "Preconceito de marca: as relaçóes raciais em Itapetininga". Revista Brasileira de Ciências Sociais, 14(41): pp. 169-171.

GUSMÃO, Neusa M. M. de. 1992. "Negro e camponês: política e identidade no meio rural brasileiro". São Paulo em Perspectiva, 6(3): pp. 116-122.

HOBSBAWN, Eric; RANGER, Terence (Orgs.). 2008. A invenção das tradiçôes. 6a edição. São Paulo: Paz e Terra. 
IANNI, Octavio. 2004a. Florestan Fernandes: sociologia crítica e militante. São Paulo: Expressão Popular.

. 2004b. "Octavio Ianni: o preconceito racial no Brasil". Estudos Avançados, 18(50): pp. 6-20.

LANDES, Ruth. 1967. A cidade das mulheres. Rio de Janeiro: Civilização Brasileira. 1947. The City of Women. New York: UNM Press.

LARAIA, Roque de Barros. 1997. "Oliveira Viana: 75 anos de evolução do povo brasileiro". Pós - Revista Brasiliense de Pós-Graduação em Ciências Sociais. Brasília: Paralelo 15.

. 1986. "Relações entre negros e brancos no Brasil". In: Cerqueira, Eli Diniz et al. O que se deve ler em ciências sociais no Brasil. São Paulo: Cortez; ANPOCS, pp. 159-173.

MAIO, Marcos Chor. 1999. "O Projeto Unesco e a agenda das ciências sociais no Brasil dos anos 40 e 50". RBCS, 14(41): pp. 141-158.

MELATTI, Julio Cezar. 1983. A antropologia no Brasil: um roteiro. Brasília: Departamento de Antropologia da Universidade de Brasília. (Série Antropologia).

MENDOZA, Edgar S. G. 2005. "Donald Pierson e a escola sociológica de Chicago no Brasil: os estudos urbanos na cidade de São Paulo (1935-1950)”. Sociologias, (14), pp. 440-470.

MORIN, Edgar. 1990. Introdução ao pensamento complexo. 2. ed. Lisboa: Instituto Piaget.

NINA RODRIGUES, Raimundo. 1939. As coletividades anormais. Rio de Janeiro: Civilização Brasileira.

1935. O animismo fetichista dos negros baianos. Rio de Janeiro: Civilizaçáo Brasileira.

. 1932. Os africanos no Brasil. São Paulo: Nacional.

NOGUEIRA, Oracy. 1955. "Relaçóes raciais no município de Itapetininga". In: Roger Bastide \& Florestan Fernandes. (Org.). Relaçóes raciais entre negros e brancos em São Paulo: ensaio sociológico sobre as Origens, as Manifestaçóes e os Efeitos do preconceito de cor no município de são Paulo. São Paulo: Unesco-Anhembi, pp. 362-554.

OLIVEIRA VIANA, Francisco J. de. 1923. Evolução do povo brasileiro. São Paulo: Nacional. 
. 1932. Raça e assimilação. São Paulo: Nacional. (Biblioteca Pedagógica Brasileira, série V; Brasiliana).

PEIRANO, Mariza. 1992. “Os antropólogos e suas linhagens”. In: Roque Laraia \& Mariza Corrêa. (Org). Roberto Cardoso de Oliveira: homenagem. Campinas: UNICAMP/ IFCH, pp. 31-47.

PIERSON, Donald. 1942. Negroes in Brazil: a Study of a Race Contact at Babia. Chicago: University of Chicago Press.

PIERSON, Donald; CUNHA, Mario W. V. da. 1947. Pesquisa e possibilidades de pesquisa no Brasil (com especial referência a "cultura" e "mudança cultural"): parte I. 9(3): pp. 233-256.

RAMOS, Arthur. 1937. As culturas negras no Novo Mundo. 4. ed. São Paulo: Nacional. . 1943. Introdução à antropologia brasileira. Rio de Janeiro: Dep. Cultural.

. 1934. O negro brasileiro: etnografia religiosa e psicanálise. Rio de Janeiro: Civilizaçáo Brasileira.

RIBEIRO, René. 1949. The Afrobrazilian Cult-Groups of Recife - a Study in Social Adjustment. Thesis (M. A.), Northwestern University.

RIOS, Ana Lugão; MATTOS, Hebe. 2005. Memórias do cativeiro: familia, trabalho e cidadania no pós-abolição. Rio de Janeiro: Civilização Brasileira.

RUBIM, Christina de R. 1996. Antropólogos brasileiros e a antropologia no Brasil: a era da pós-graduação. Tese de doutorado, Universidade Estadual de Campinas.

SCHWARCZ, Lilia M. 2007. O espetáculo das raças: cientistas, instituições e questão racial no Brasil (1870-1930). São Paulo: Companhia das Letras. Publicado originalmente em 1993.

WAGLEY, Charles. 1952. Races et classes dans le Brésil rural. Paris: Unesco.

WOORTMANN, Klaas. 1990. Com parente não se neguceia. Anuário Antropológico, (87): pp. 11-73. Brasília: Editora da Universidade de Brasília; Rio de Janeiro: Tempo Brasileiro. 


\section{Resumo}

Proponho, neste artigo, traçar uma breve análise dos estudos sobre relaçóes raciais, nas ciências sociais no Brasil, com o intuito de demonstrar que o foco dos estudos sociológicos e antropológicos sobre o negro estava delimitado predominantemente em contextos urbanos até a década de 1960. As comunidades negras rurais, vistas como "desagregadas culturalmente", foram colocadas à margem desses estudos no período citado. Esse quadro só começou a ser modificado com a criaçáo dos programas de pós-graduaçáo em antropologia, os quais investigaram múltiplos temas que, aos poucos, deram visibilidade às comunidades negras rurais.

Palavras-chave: comunidades negras rurais, ciências sociais, relaçóes raciais, PPGAs.

\section{Abstract}

I propose, in this article, to outline the studies on race relations in Brazilian social sciences in order to demonstrate that sociological and anthropological studies about black populations were predominantly limited to urban contexts until the 1960s. Rural black communities, seen as "culturally broken", were placed in the margins of these studies. This situation only began to be modified with the creation of graduate programs in anthropology, whose researchers investigated multiple themes that gradually shed light on rural black communities.

Keywords: rural black communities, social sciences, race relations, PPGAs. 